\title{
Cellular Retinol-Binding Protein-1 Expression and Modulation during In Vivo and In Vitro Myofibroblastic Differentiation of Rat Hepatic Stellate Cells and Portal Fibroblasts
}

\author{
Kozue Uchio, Beatriz Tuchweber, Noboru Manabe, Giulio Gabbiani, \\ Jean Rosenbaum, and Alexis Desmoulière
}

Groupe de Recherches pour l'Etude du Foie (KU, JR, AD), Université Victor Segalen Bordeaux 2, Bordeaux, France; Département de Nutrition (BT), Université de Montréal, Montréal, Québec, Canada; Unit of Anatomy and Cell Biology (NM), Department of Animal Sciences, Kyoto University, Kyoto, Japan; and Department of Pathology (GG), Centre Médical Universitaire, Geneva, Switzerland

SUMMARY: Cellular retinol-binding protein-1 (CRBP-1) is involved in vitamin A metabolism because it mediates both retinol esterification to retinyl esters and retinol oxidation to retinal and retinoic acid. CRBP-1 is highly expressed in the liver, particularly in hepatic stellate cells (HSC). In this study, we investigated the liver expression of CRBP-1 during experimental fibrogenesis. We also studied the regulation of CRBP-1 expression in cultured HSC and portal fibroblasts, two fibroblastic cell types involved in liver fibrogenesis. Fibrosis was induced in rats by carbon tetrachloride $\left(\mathrm{CCl}_{4}\right)$ or bile duct ligation. Immunohistochemical staining was performed for CRBP-1 and $\alpha$-smooth muscle (SM) actin, an activation marker of fibrogenic cells. CRBP-1 and $\alpha$-SM actin expression was studied by Western blotting and/or Northern blot in primary cultures of HSC isolated by conventional methods and in portal fibroblasts that were obtained by outgrowth from the biliary tree after enzymatic digestion. In normal liver, contrary to $\mathrm{HSC}$, portal fibroblasts did not express CRBP-1. After $\mathrm{CCl}_{4}$ injury, CRBP-1 expression was maintained in myofibroblastic $\alpha$-SM actin-positive HSC. After bile duct ligation, portal fibroblasts (which proliferated around ductular structures) acquired expression of both CRBP-1 and $\alpha$-SM actin. During HSC activation in culture, CRBP-1 expression gradually increased until Day 5 when $\alpha$-SM actin expression was obvious. Cultured portal fibroblasts developed both CRBP-1 and $\alpha$-SM actin expression. In both cell populations, transforming growth factor- $\beta 1$ treatment increased CRBP-1 expression. Thus, in normal liver, CRBP- 1 expression was different among fibroblastic cells, a finding that adds to the concept of heterogeneity of liver fibrogenic cells. Furthermore, during myofibroblastic differentiation, HSC that lost their stores of retinol maintained a high level of CRBP-1 expression, whereas portal fibroblasts acquired CRBP1 expression. Together, these data suggest a correlation between CRBP-1 expression and myofibroblastic differentiation. (Lab Invest 2002, 82:619-628).

\begin{abstract}
7 he uptake, intracellular transport, and metabolism of retinol (vitamin $A$ ) are regulated by cellular retinol-binding proteins (CRBP-1 and CRBP-2), whereas the cellular retinoic acid-binding proteins exert the same function for retinoic acid (Blomhoff, 1994). Retinoic acid has been shown to influence the expression of many genes through interactions between retinoic acid receptors and the retinoic acid response element located in promoter regions. Unlike retinoic acid receptors, retinoid-binding proteins modulate the effect of retinoic acid by regulating its intracellular level. CRBPs provide the substrate for retinoic
\end{abstract}

Received February 1, 2002.

$K U$ was a recipient of a fellowship from the Japan Society for the Promotion of Science. This work was supported in part by the Région Aquitaine, the Swiss National Science Foundation (grant 31-61336.00), and the Medical Research Council of Canada.

Address reprint requests to: Dr. Alexis Desmoulière, GREF, INSERM E9917, Université Victor Segalen Bordeaux 2, 146, rue Léo-Saignat, 33076 Bordeaux cedex, France. E-mail: Alexis.Desmouliere@gref.u-bordeaux2.fr acid biosynthesis, whereas cellular retinoic acidbinding proteins are substrates for retinoic acid catabolism. The liver is the most important organ for the metabolism, storage, and homeostasis of retinoids. Hepatocytes play a major role in the primary uptake and processing of retinoids, whereas hepatic stellate cells (HSC; Ito cells, perisinusoidal cells, fat-storing cells, lipocytes) located in the perisinusoidal space, are the main storage site for retinoids in normal liver (Hendriks et al, 1985). It has been shown that vitamin A deficiency in rats potentiates liver fibrosis induced by carbon tetrachloride $\left(\mathrm{CCl}_{4}\right)$ (Seifert et al, 1994), whereas administration of retinol inhibits $\mathrm{CCl}_{4}^{-}$ induced fibrosis (Senoo and Wake, 1985) and collagen synthesis by HSC (Shiratori et al, 1987). On the other hand, chronic hypervitaminosis A results in severe liver fibrosis in human by a poorly understood mechanism (Farrell et al, 1977; Russell et al, 1974). Altogether, these findings support a mechanistic link between vitamin $A$ metabolism and the activation of fibrogenic cells. 
CRBP-1 is expressed mainly in liver, kidney, and the genital tract; CRBP-2 is confined to the small intestine (Ong et al, 1994). Several studies have examined the expression of CRBP-1 in the different cell types of the liver (Blaner et al, 1985; Blomhoff et al, 1985; Kato et al, 1984). Hepatocytes and HSC contain large amounts of CRBP-1. Although hepatocytes account for more that $90 \%$ of hepatic CRBP-1, the concentration of the protein in HSC (per unit protein) is 22 times higher than that in hepatocytes (Blomhoff et al, 1985). CRBP-1 is usually not expressed in skin. However, during wound healing of a full-thickness rat skin wound, CRBP-1 is transiently expressed by a significant proportion of fibroblastic cells, including myofibroblasts (Xu et al, 1997), suggesting that it plays a role in the evolution of the granulation tissue. Although it is well established that HSC play an important role in liver fibrogenesis (Pinzani and Gentilini, 1999), other fibroblastic cells can also be involved in the development of liver fibrosis. Specifically, it has been shown that portal fibroblasts are involved in the fibrotic lesions that develop around portal areas after bile duct ligation in the rat (Desmoulière et al, 1997; Tuchweber et al, 1996). Further evidence for the heterogeneity of liver fibrogenic cells has been brought by Knittel et al (1999a, 1999b) who have described different fibroblastic cell populations involved in liver fibrosis.

The aim of this work was to study CRBP-1 protein and mRNA expression in the different myofibroblastic subpopulations appearing during experimental liver fibrosis, and in cultured hepatic fibroblastic cells. Our data confirm the presence of different fibroblastic subpopulations developing a myofibroblastic phenotype during fibrosis and expressing CRBP-1; they also suggest a correlation between CRBP-1 expression and the appearance of $\alpha$-smooth muscle (SM) actin in activated hepatic fibroblastic cells involved in fibrogenesis.

\section{Results}

Hematoxylin-Eosin and Sirius Red Staining Examination in Normal and Fibrotic Rat Liver

In normal liver, Sirius red staining was observed around centrolobular veins and in portal connective tissue around bile ducts and vessels (Fig. 1a). In the parenchyma, very few bundles were observed. In $\mathrm{CCl}_{4}$-treated animals, a marked inflammatory reaction and hepatocytic necrosis were observed around centrolobular veins at 48 hours. Occasionally, bridging necrosis was observed. Histologic signs of liver necrosis peaked at 48 hours after a single dose of $\mathrm{CCl}_{4}$. Then, a fibrotic lesion developed with a progressive accumulation of Sirius red stained materials around centrolobular veins leading to the formation of septa (Fig. 1b). At 72 hours after bile duct ligation, bile duct proliferation was clearly evident, whereas very few inflammatory cells were detected in the portal tracts. At this time, fibrous tissue deposition in portal areas was noted as previously described (Desmoulière et al, 1997). At 5 and 7 days after bile duct ligation, bile duct proliferation progressively penetrated into the parenchyma with a parallel deposition of Sirius red stained materials (Fig. 1c).
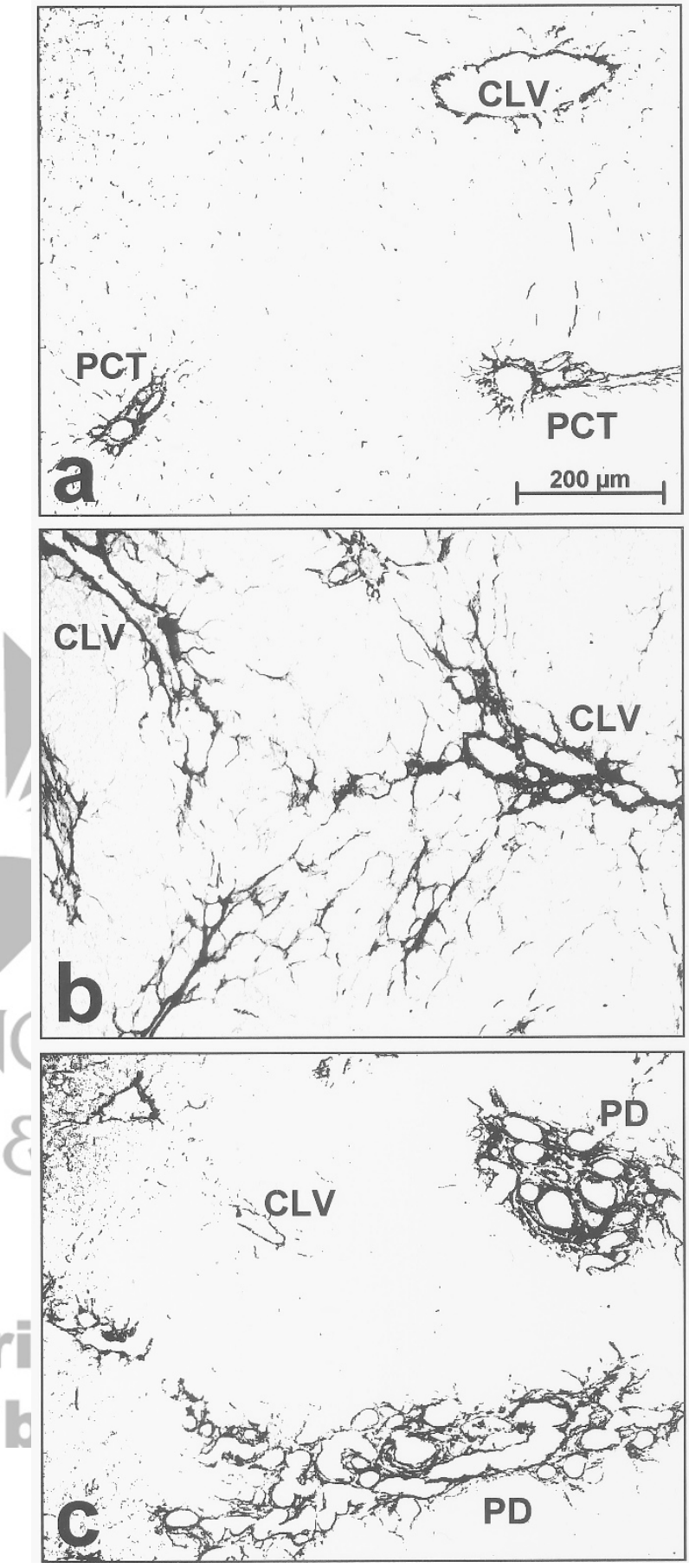

Figure 1.

Sirius red staining in control liver (a), after carbon tetrachloride $\left(\mathrm{CCl}_{4}\right)$ treatment for 2 weeks (b), or after bile duct ligation for 7 days (c). In control liver (a), collagen deposition is present only around the centrolobular vein (CLV) and in portal connective tissue (PCT). In experimental models of fibrosis, staining underlines the different localizations of the collagen deposition, around centrolobular veins (CLV) leading to the formation of septa after $\mathrm{CCl}_{4}$ treatment (b), and around proliferating ductules $(P D)$ after bile duct ligation (c).

\section{CRBP-1 and $\alpha$-SM Actin Expression in Normal and Fibrotic Rat Liver}

In normal liver, $\alpha$-SM actin was exclusively expressed in vessel walls (centrolobular veins, portal veins, and 
arteries; Fig. 2a). CRBP-1 was expressed at a high level in HSC and slightly in hepatocytes as previously described (Kato et al, 1984); in the parenchyma, the distribution of CRBP-1-expressing HSC was homogeneous. In portal areas, the fibroblastic cells did not express CRBP-1 (Fig. 2b).
In $\mathrm{CCl}_{4}$-treated animals, at 2 and 6 weeks, numerous cells expressed $\alpha$-SM actin in the region where fibrosis developed (Fig. 2c) and the expression of CRBP-1 was maintained in the HSC located in these areas (Fig. 2d). Double immunohistochemistry showed that the majority of $\alpha$-SM actin-positive cells ex-
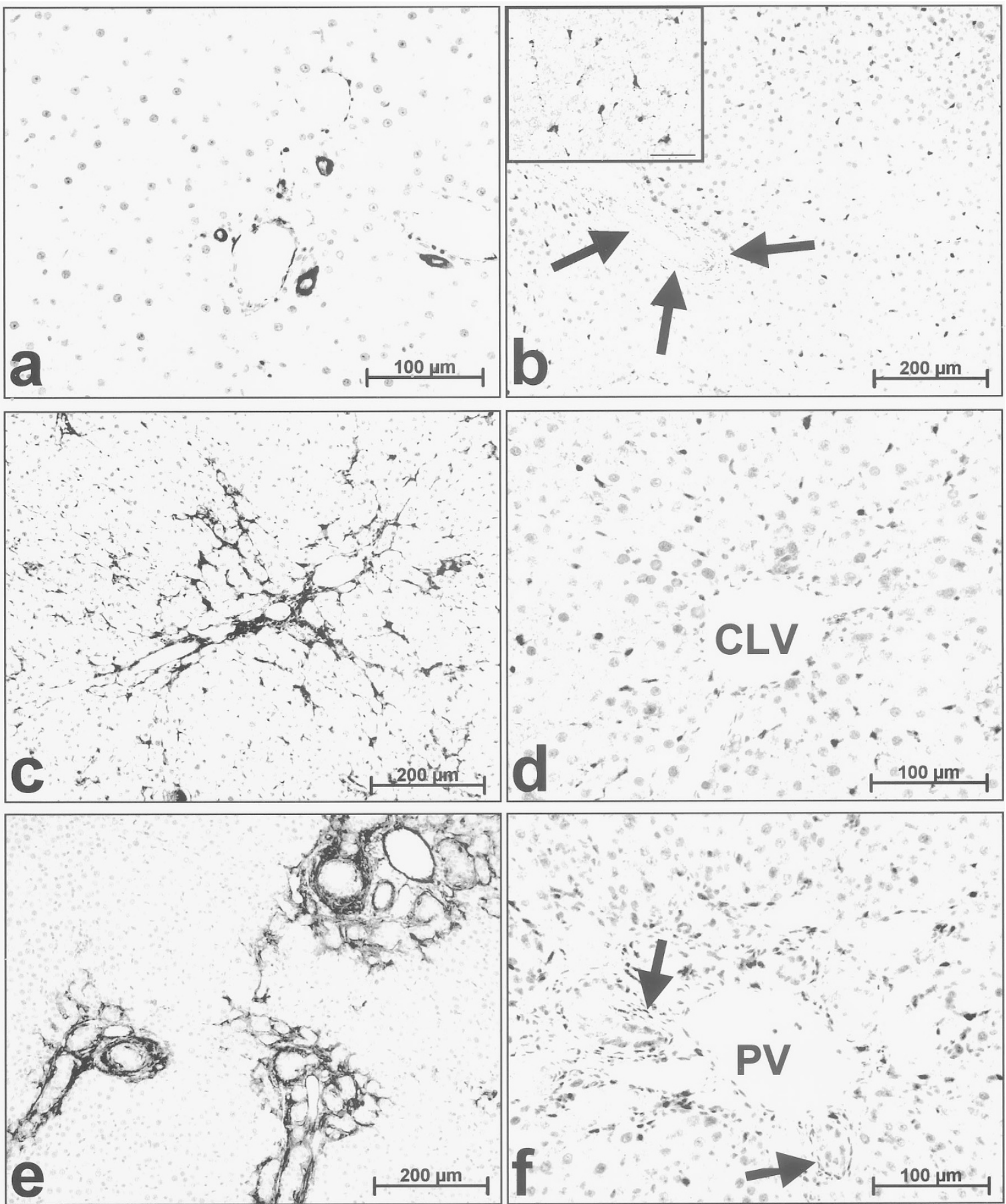

Figure 2.

$\alpha$-Smooth muscle (SM) actin (a, c, e) and cellular retinol-binding protein-1 (CRBP-1) (b, d, f) immunostaining in control liver (a, b), after $\mathrm{CCl}_{4}$ treatment for 2 weeks (c, d), or after bile duct ligation for 7 days (e, f). In control liver, $\alpha$-SM actin (a) is exclusively observed in vessel walls (centrolobular veins, portal veins, and arteries); hepatic stellate cells (HSC) of the parenchyma strongly express CRBP-1 (b, inset), whereas no expression is observed in the portal zone (b, arrows). After CCl ${ }_{4}$ treatment, activated HSC that proliferate around the centrolobular vein express $\alpha$-SM actin (c); many cells with a fibroblastic morphology express CRBP-1 in the CLV area (d). After bile duct ligation, portal fibroblasts that proliferate around ductules express $\alpha$-SM actin (e); many portal fibroblastic cells, particularly around ductules, express CRBP-1 (f, arrows; PV: portal vein). 
pressed CRBP-1 (Fig. 3a). In the parenchyma, at a distance from centrolobular vein areas, the expression of CRBP-1 in sinusoidal cells was not drastically modified as compared with normal liver.

After bile duct ligation, the portal fibroblastic cells that proliferated together with the progressive development of biliary structures acquired an $\alpha$-SM actinpositive myofibroblastic phenotype (Fig. 2e); around biliary structures, many cells forming onion-like layers and showing a (myo)fibroblastic morphology expressed CRBP-1 (Fig. 2f). Double immunohistochemistry showed that the majority of these $\alpha$-SM actinpositive portal myofibroblasts located around proliferating ductules expressed CRBP-1 (Fig. 3b). In the parenchyma around portal areas, the distribution of CRBP-1-positive HSC remained homogeneous, similar to that observed in control liver.

\section{CRBP-1 and $\alpha-S M$ Expression in Cultured Rat Hepatic Fibroblastic Cells}

As previously described (Ramadori et al, 1990; Rockey et al, 1992), $\alpha$-SM actin expression was not seen in primary HSC 24 hours after plating, but was detected after 3 days in culture (data not shown). At 24 hours after plating, primary HSC expressed CRBP-1 and this expression increased after 3 and 5 days in culture (Fig. 4). As previously described (Bachem et al, 1993), $\alpha$-SM actin expression was increased by transforming growth factor- $\beta 1$ (TGF- $\beta 1$ ) treatment (not shown). TGF- $\beta 1$ treatment also increased the expression of CRBP-1 (Fig. 4) at 3 and 5 days ( $p<0.05$ compared with untreated cells). The effect of TGF- $\beta 1$ treatment was confirmed in HSC-T6 cells with a dose-response effect: compared with untreated cells, TGF- $\beta 1$ treatment increased $\alpha$-SM actin protein expression (Fig. $5 \mathrm{a})$ at 1 and $2.5 \mathrm{ng} / \mathrm{ml}(p<0.05)$ with a plateau from 5 $\mathrm{ng} / \mathrm{ml}(p<0.01)$. TGF- $\beta 1$ also increased CRBP-1 protein expression (Fig. $5 \mathrm{~b}$ ) at $1 \mathrm{ng} / \mathrm{ml}$ with a plateau from $2.5 \mathrm{ng} / \mathrm{ml}(p<0.01)$. After hybridization of RNA with CRBP-1 and GAPDH probes, two bands were obtained, one at $1.4 \mathrm{~kb}$ corresponding to GAPDH mRNA, and one at $0.7 \mathrm{~kb}$ corresponding to CRBP-1 mRNA (Sherman et al, 1987). In HSC-T6, CRBP-1 mRNA expression was increased by TGF- $\beta 1$ treatment with a plateau from $2.5 \mathrm{ng} / \mathrm{ml}(p<0.01 \mathrm{com}-$ pared with untreated cells (Fig. $5 \mathrm{c}$ ).

Because our in vivo data pointed to a neoexpression of CRBP-1 in portal fibroblasts after bile duct ligation, we devised a method to grow these cells in culture. Figure 6a shows an immunostaining for cytokeratin 7 in the biliary structures that were obtained by enzymatic digestion. In these biliary structures, neither $\alpha$-SM actin expression nor CRBP-1 expression were detected, but vimentin-expressing cells were observed (not shown). After 24 to 48 hours in culture, portal fibroblastic cells developed by outgrowth from these biliary structures; these cells did not contain

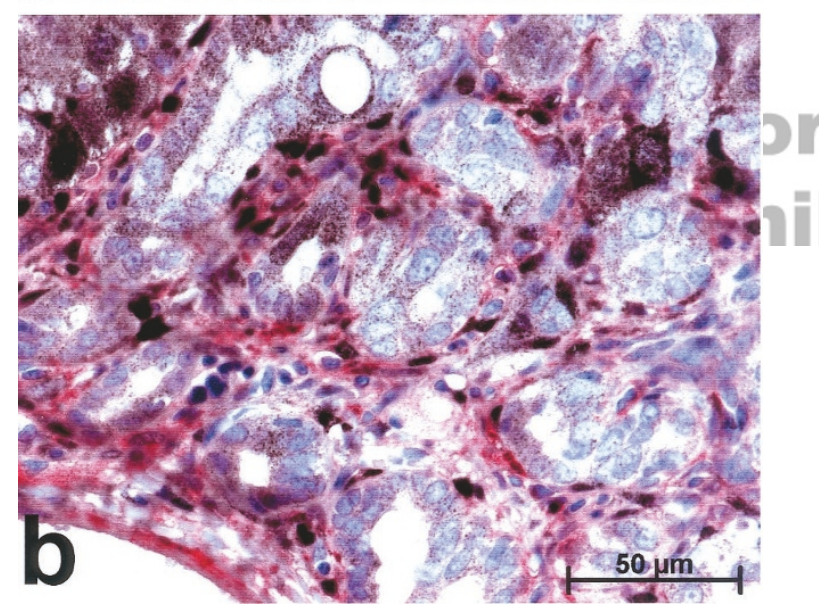

Figure 3.

Double immunostaining for $\alpha$-SM actin (in red) and CRBP-1 (in dark brown) after $\mathrm{CCl}_{4}$ treatment for 2 weeks (a), or after bile duct ligation for 7 days (b). After $\mathrm{CCl}_{4}$ treatment (a), the majority of $\alpha$-SM actin-positive cells strongly express CRBP-1; a slight staining (compared with $\alpha$-SM actin-expressing myofibroblastic cells) is observed in hepatocytes, although some hepatocytes close to the proliferating myofibroblasts present a strong staining. After bile duct ligation (b), around the proliferating ductules, the majority of $\alpha$-SM actin positive portal myofibrolastic cells strongly express CRBP-1.

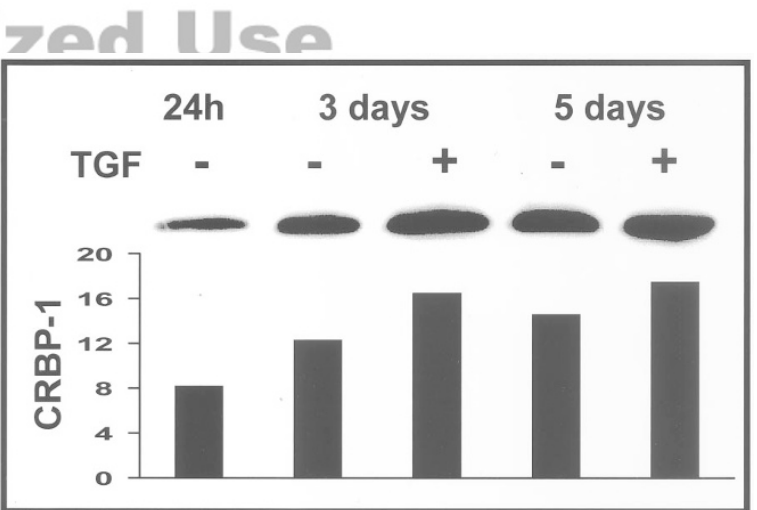

Figure 4.

Immunoblotting for CRBP-1 of HSC primary culture total protein extracts; effect of TGF- $\beta 1$ treatment. Compared with control, CRBP-1 expression gradually increases under culture conditions at 3 and 5 days after plating ( $p<$ 0.05 ); compared with untreated cells, 3 days and 5 days incubations with TGF- $\beta 1(5 \mathrm{ng} / \mathrm{ml})$ increase CRBP- 1 expression $(p<0.05)$. The histogram represents the mean of three different primary HSC isolations and cultures. Standard error of means are not represented in the figure, but were always lower than $5 \%$ of values. 

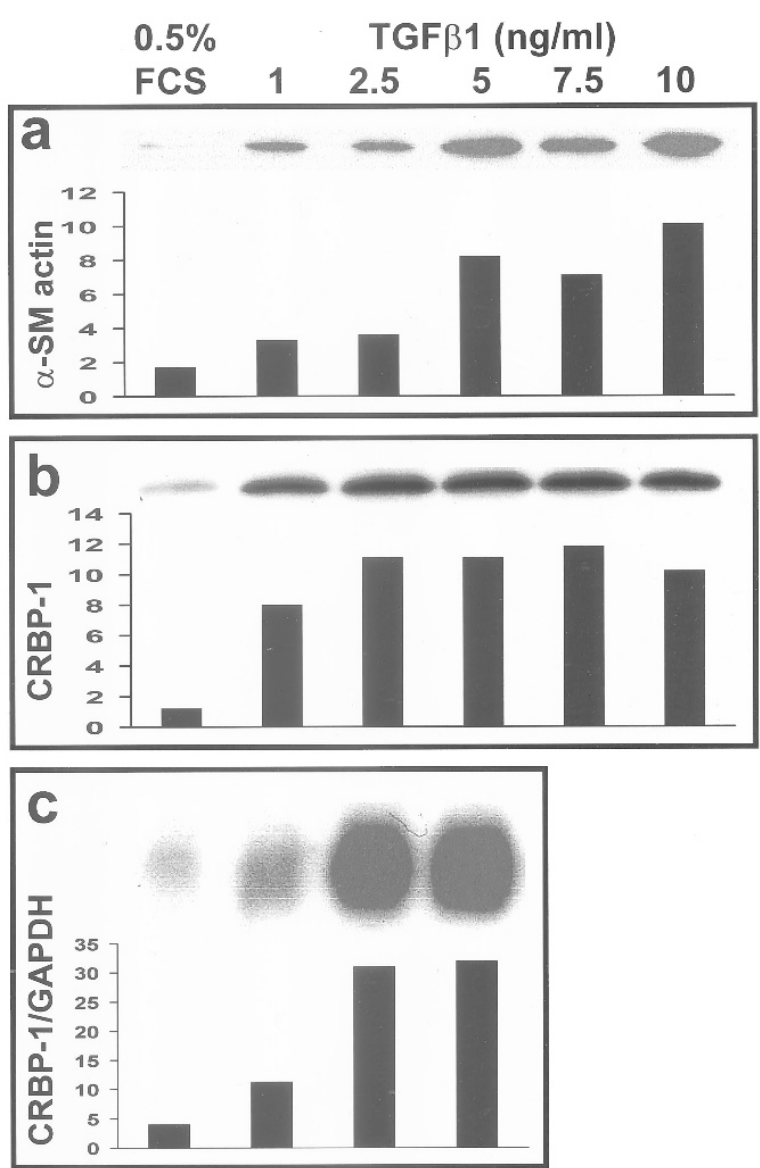

Figure 5.

Immunoblotting for $\alpha$-SM actin (a) and CRBP-1 (b) of HSC-T6 total proteins and Northern blot for CRBP-1 (c) of HSC-T6 total mRNA extracts; HSC-T6 are untreated or treated with different doses of TGF- $\beta 1(n=3)$. The treatment with TGF- $\beta 1$ increases both $\alpha$-SM actin and CRBP- 1 expression with a plateau at 5 $\mathrm{ng} / \mathrm{ml}$ for $\alpha$-SM actin and $2.5 \mathrm{ng} / \mathrm{ml}$ for CRBP-1. Northern blot shows an increase of the CRBP-1 mRNA expression with a plateau at $2.5 \mathrm{ng} / \mathrm{ml}$. Standard error of means are not represented in the figure, but were always lower than $10 \%$ of values.

lipid droplets. They expressed $\alpha$-SM actin (Fig. 6b) and vimentin (not shown) as evaluated by immunofluorescence. In our culture conditions, no von Willebrand factor was detected in primary culture, and the few bile duct cells expressing cytokeratin 7 observed in the first passage were no longer present after trypsinization. These portal myofibroblastic cells expressed laminin (Fig. 6b), collagen type IV (Fig. 6c), and the EIIIA isoform of fibronectin (Fig. 6d). TGF- $\beta 1$ treatment increased with a dose-response effect $\alpha$-SM actin expression (Fig. 7a; $p<0.05$ for 1 and 2.5 $\mathrm{ng} / \mathrm{ml}$, and $p<0.01$ for $5 \mathrm{ng} / \mathrm{ml}$ compared with untreated cells). In our culture conditions in the presence of serum, these portal fibroblastic cells expressed CRBP-1. TGF- $\beta 1$ treatment also increased with a dose-response effect CRBP-1 protein expression (Fig. $7 \mathrm{~b} ; p<0.05$ for 1 and $2.5 \mathrm{ng} / \mathrm{ml}$, and $p<$ 0.01 for $5 \mathrm{ng} / \mathrm{ml}$ compared with untreated cells). In these portal myofibroblastic cells, CRBP-1 mRNA expression was increased by TGF- $\beta 1$ treatment (Fig. $7 \mathrm{c} ; p<0.05$ for $1 \mathrm{ng} / \mathrm{ml}$, and $p<0.01$ for 2.5 and 5 $\mathrm{ng} / \mathrm{ml}$ compared with untreated cells).

\section{Discussion}

In our study, by using different experimental models of liver fibrosis in rats, we show by immunohistochemistry that myofibroblasts derived from $\mathrm{HSC}$ or from portal fibroblasts express CRBP-1. HSC expressed CRBP-1 both in normal liver and when they were involved in myofibroblastic differentiation during liver fibrosis induced by $\mathrm{CCl}_{4}$ treatment. Portal fibroblasts that did not express CRBP-1 in normal liver acquired CRBP-1 expression during myofibroblastic differentiation induced by bile duct ligation.

To better understand the regulation of CRBP-1 expression, we performed in vitro studies. We show that CRBP-1 expression increased with the cultureinduced activation of freshly isolated HSC. Portal fibroblasts encased in isolated biliary structures were initially negative for CRBP-1, but became positive after a few days in culture. Modifications of CRBP-1 expression were accompanied by parallel variations in $\alpha$-SM actin expression. Furthermore, we show that TGF- $\beta 1$, a fibrogenic mediator involved in both myofibroblastic differentiation and extracellular matrix deposition, induced CRBP-1 protein and mRNA expression in primary cultures of HSC, in the HSC-T6 cell line, and in portal fibroblasts.

The role of HSC in extracellular matrix deposition and fibrogenesis is well known and has been largely studied (for review, see Pinzani and Gentilini, 1999). The myofibroblastic differentiation of HSC is associated with a decrease in total hepatic vitamin $\mathrm{A}$ (Kent et al, 1976). To our knowledge, the expression of CRBP-1 in $\mathrm{CCl}_{4}$-treated rats has not been studied. In this model, we have observed that HSC involved in tissue repair maintained a high level of CRBP-1 expression. In vitro studies with the HSC line GRX and HSC-T6 have shown that treatment with retinol increased CRBP-1 mRNA (Vicente et al, 1998; Vogel et al, 2000). After $\mathrm{CCl}_{4}$ treatment in rats, hepatic levels of retinyl palmitate, which is the predominant storage form of vitamin A in rat HSC (Blomhoff et al, 1985; Hendricks et al, 1985), are decreased, whereas levels of retinol, which is the transport form of vitamin $A$ (Blomhoff et al, 1990), are increased (Yamane et al, 1993). It is thus possible that the stable expression of CRBP-1 in HSC after $\mathrm{CCl}_{4}$ treatment is under the control of the free retinol level.

Additionally, our in vitro data, both in primary HSC and in the HSC-T6 cell line, show that TGF- $\beta 1$ upregulated $\mathrm{CRBP}-1$ at the protein and mRNA levels. TGF- $\beta 1$ is increased in $\mathrm{CCl}_{4}$-induced fibrotic rat liver (De Bleser et al, 1997) and could thus also directly account for the expression of CRBP-1 in vivo. Furthermore, HSC cultured on a collagen type I matrix contain approximately five times more CRBP-1 than do cells grown on a collagen type IV matrix (Davis et al, 1987), which suggests that type I collagen deposition induced by the enhanced TGF- $\beta 1$ expression observed during liver fibrosis may also play a role in the induction of CRBP-1 expression. An effect of TGF- $\beta 1$ on CRBP-1 expression has already been reported by $\mathrm{Xu}$ et al (1997) in different nonliver fibroblastic popula- 

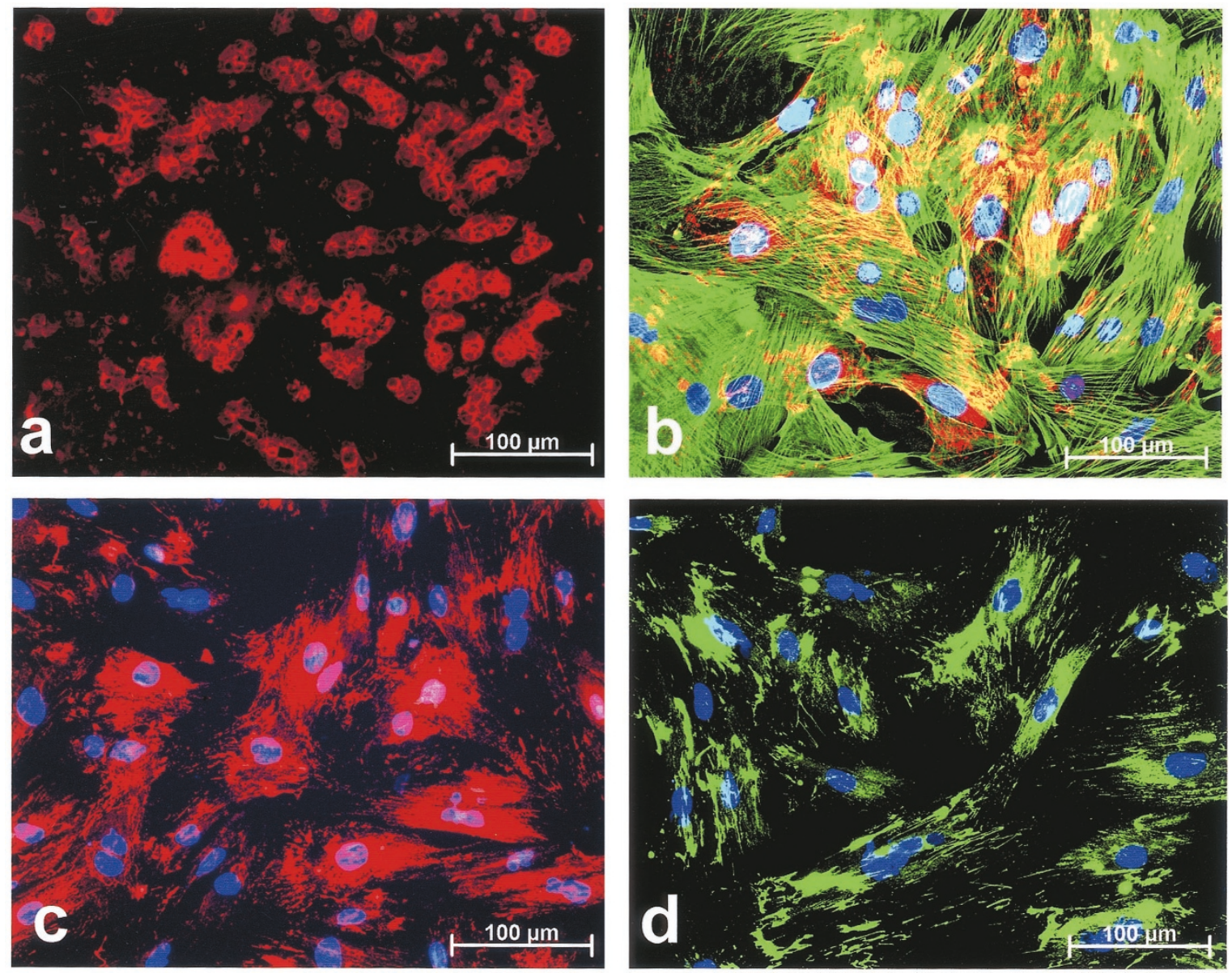

Figure 6.

Immunofluorescence staining of biliary structure preparation (a) and of portal fibroblasts in culture $(\mathrm{b}-\mathrm{d})$. Biliary structures obtained by enzymatic digestion express cytokeratin 7 (a). Portal fibroblasts show stress fibers strongly positive for $\alpha$-SM actin (in green) and express laminin (in red) (b; yellow illustrates a colocalization); portal fibroblasts also express collagen type IV (c) and the EIIID domain of fibronectin (d). In b, c, and d, nuclei are stained with DAPI.

tions. Recently, it has been suggested that, in cultured rat subcutaneous tissue fibroblasts, the action of retinoic acid on the TGF- $\beta$ pathway induces a reduction in the expression of both CRBP- 1 and $\alpha$-SM actin (Xu et al, 2001). We can assume that, when the hepatic retinoic acid level decreases after liver injury, the action of TGF- $\beta$ on myofibroblastic differentiation can develop.

Indeed, it has been observed that different fibroblastic subpopulations are involved in liver fibrosis (Bhunchet and Wake, 1992; Knittel et al, 1999a, 1999b) and the role of portal fibroblasts has been particularly highlighted (Tuchweber et al, 1996). To study the expression of CRBP-1 in portal fibroblasts, we devised a method to grow these cells in culture. To our knowledge, it is the first time that these cells have been cultured and characterized. Isolated bile duct structures were mainly composed of epithelial cells, as shown by cytokeratin 7 staining. Vimentin staining demonstrated also the presence of mesenchymal cells that were negative for $\alpha$-SM actin at the time of isolation. CRBP-1 staining was also negative, mimicking the in vivo situation. After culture initiation, a cell outgrowth was quickly observed. Outgrowing cells expressed $\alpha$-SM actin and extracellular matrix com- ponents such as laminin, collagen type IV, and the EIIIA isoform of fibronectin. Most notably, these cells developed CRBP-1 expression in vitro. Because TGF- $\beta 1$ is up-regulated in periportal areas after bile duct ligation (Milani et al, 1991), it may be responsible for the neoexpression of CRBP-1 in portal fibroblasts in vivo. In this model, we did not detect clear modifications of CRBP-1 expression in lobular HSC. In contrast, Ohata et al (1997), using the same model, have shown that the mRNA expression of CRBP-1 was drastically reduced in isolated HSC. There are no ready explanations for this apparent discrepancy. The pattern of CRBP-1 expression in portal fibroblasts is similar to that observed in subcutaneous tissue fibroblasts or in arterial SM cells that, after injury, rapidly acquire CRBP-1 expression (Neuville et al, 1997; Xu et al, 1997). The expression of CRBP-1 by arterial SM cells during arterial repair, by myofibroblasts during skin wound healing, and by portal fibroblasts during liver reaction to bile duct ligation supports the possibility that CRBP-1 plays a role in repair phenomena.

It is well known that retinoids exert significant effects on a variety of cellular processes, including growth and differentiation (Ross, 1993a, 1993b), and CRBP-1, which regulates uptake, intracellular trans- 

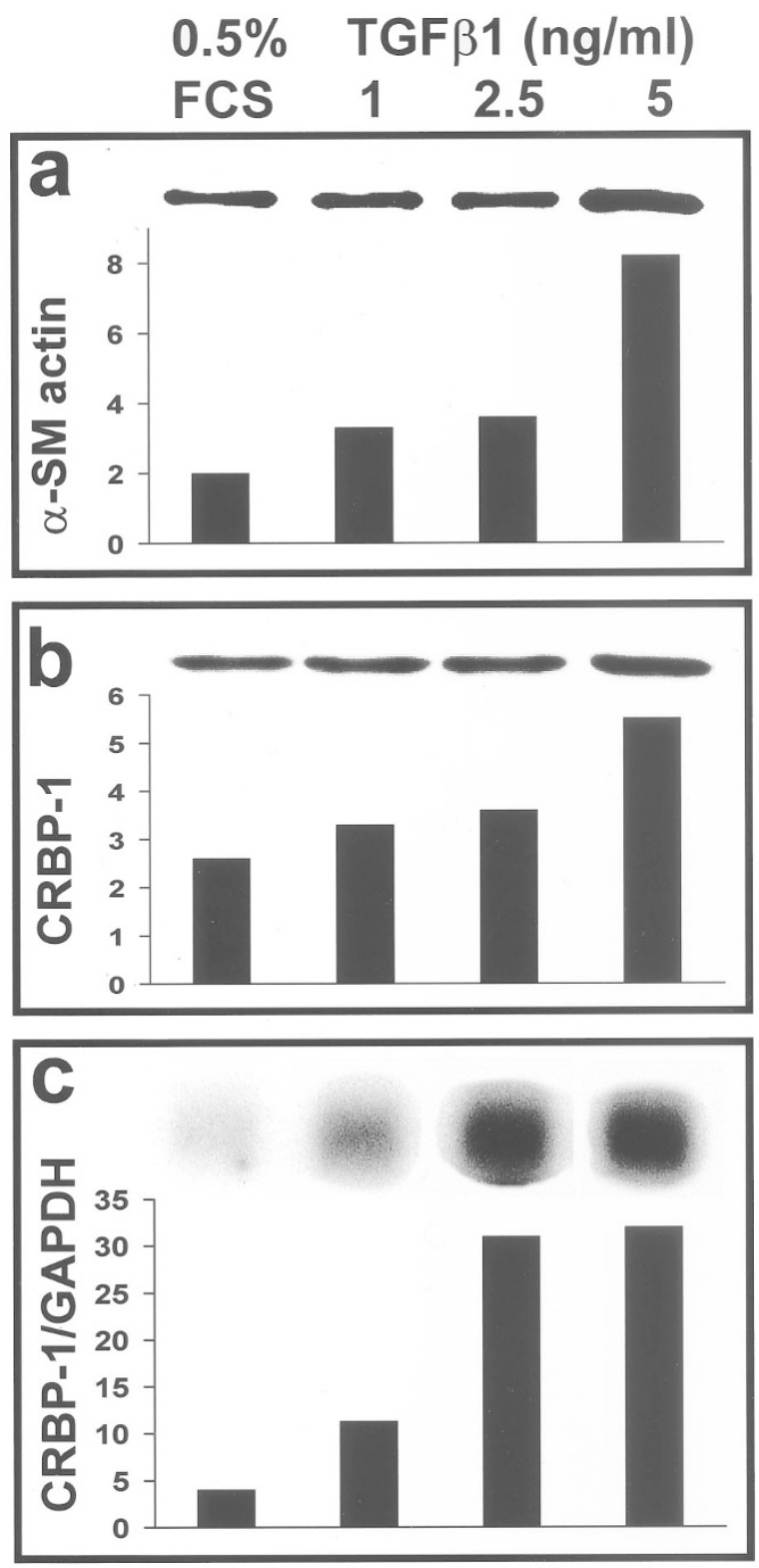

Figure 7.

Immunoblotting for $\alpha$-SM actin (a) and CRBP-1 (b) of portal fibroblast total protein extracts and Northern blot for CRBP-1 (c) of portal fibroblast total mRNA extracts; portal fibroblasts are untreated or treated with different doses of TGF- $\beta 1(n=3)$. The treatment with TGF- $\beta 1$ increases both $\alpha$-SM actin (a) and CRBP-1 (b) protein expression. Northern blot shows an increase of the CRBP-1 mRNA expression with a plateau at $2.5 \mathrm{ng} / \mathrm{ml}$. Standard error of means are not represented in the figure, but were always lower than $10 \%$ of values.

port, and metabolism of retinol, is likely involved in these important functions. However, the relationships between CRBP-1 expression and tissue repair remain to be elucidated.

In conclusion, this study on hepatic CRBP-1 expression allows characterization of at least two fibroblastic subpopulations in normal liver: HSC that highly express CRBP-1 and portal fibroblasts that do not. When involved in myofibroblastic differentiation, both populations express CRBP-1. These data suggest that CRBP-1 in these cells is not exclusively devoted to intracellular transport and esterification of retinol and that it may play a role in hepatic tissue repair.

\section{Materials and Methods}

\section{Experimental Animals}

Male Sprague-Dawley rats (initial body weight approximately $200 \mathrm{~g}$ ) were used. In the first group $(n=16)$, animals were given $\mathrm{CCl}_{4}(375 \mu \mathrm{l} / \mathrm{kg}$ of body weight in olive oil per os) three times per week. The animals were killed 48 hours after the first $\mathrm{CCl}_{4}$-treatment ( $n=$ $4)$ and at 96 hours $(n=4), 2$ weeks $(n=4)$, and 6 weeks $(n=4)$. In the second group $(n=12)$, animals were subjected to common bile duct ligation as previously described (Tuchweber et al, 1996). The animals were killed at 72 hours $(n=4), 5$ days $(n=4)$, and 7 days $(n=4)$ after bile duct ligation. Control animals were used in each case: olive oil per os for the $\mathrm{CCl}_{4}$ model $(n=4)$, and sham-operated for the bile duct ligation model $(n=4)$; some animals $(n=4)$ did not undergo any treatment. No differences were observed between any of these control groups. All animal protocols were in full compliance with the Institut National de la Santé et de la Recherche Médicale and the Bordeaux University guidelines for animal care.

\section{Processing of Rat Liver Tissue}

Tissues were fixed in $4 \%$ formaldehyde and embedded in paraffin. Sections were stained with hematoxylin-eosin for routine histology and with Sirius red (saturated picric acid in distilled water containing $0.1 \%(w / v)$ Sirius red F3B (BDH Chemicals Ltd., Poole, United Kingdom) to allow visualization of fibrosis (Manabe et al, 1993). After Sirius red staining, the sections were not counterstained. Tissue samples derived from normal liver, from liver after $\mathrm{CCl}_{4}$ treatment, or bile duct ligation were frozen in liquid nitrogen and used for protein and mRNA extraction.

\section{Antibodies}

For immunohistochemistry and/or immunofluorescence on cultured cells, the following antibodies were used: a mouse monoclonal antibody (lgG2a) against $\alpha$-SM actin (Dako A/S, Glostrup, Denmark; Skalli et al, 1986), an affinity-purified rabbit polyclonal antibody against CRBP-1 (Neuville et al, 1997), monoclonal antibodies against vimentin and cytokeratin 7 (Dako $\mathrm{A} / \mathrm{S})$, a polyclonal rabbit antibody against human von Willebrand factor (Dako A/S), affinity-purified rabbit polyclonal anti-mouse laminin and anti-mouse collagen type IV antibodies (gift of Dr. Schuppan, Department of Gastroenterology, Friedrich-Alexander University, Erlangen, Germany), and a monoclonal antibody (IgG1) specific to the EIIIA domain of fibronectin (IST-9; gift of Dr. Zardi, Cell Biology Laboratory, Istituto Nazionale per la Ricerca sul Cancro, Genoa, Italy; Borsi et al, 1987). All of these antibodies have been extensively used and their specificity has been clearly documented. 


\section{Immunohistochemistry}

For simple immunohistochemistry, 5- $\mu \mathrm{m}$ paraffin sections were cut. The sections were deparaffinized, hydrated, washed with Tris buffered saline, and incubated with $3 \% \mathrm{H}_{2} \mathrm{O}_{2}$ in methanol to inhibit endogenous peroxidase. Then, sections were incubated with anti- $\alpha$ SM actin or anti-CRPB-1 diluted $1 / 250$ or $1 / 500$, respectively, with Tris buffered saline at room temperature for 30 minutes. After incubation with Envisionhorseradish peroxidase mouse or rabbit (Dako A/S) at room temperature for 30 minutes, the sections were treated with $1 \mathrm{mg} / \mathrm{ml}$ diaminobenzidine and $0.1 \%$ $\mathrm{H}_{2} \mathrm{O}_{2}$ in $0.05 \mathrm{~m}$ Tris- $\mathrm{HCl}(\mathrm{pH}$ 7.6) at room temperature for 30 minutes. For CRBP-1 staining, sections were previously heated by using a pressure cooker in $0.01 \mathrm{M}$ citrate buffer ( $\mathrm{pH} \mathrm{6.0)}$ ) at $120^{\circ} \mathrm{C}$ for 5 minutes.

For double immunohistochemistry, sections were first incubated with anti- $\alpha$-SM actin, Envision-Alkaline Phosphatase (Dako A/S), and New Fuchsin (Dako A/S). Then, the sections were incubated with $3 \% \mathrm{H}_{2} \mathrm{O}_{2}$ in methanol to inhibit endogenous peroxidase. After heating by using a pressure cooker, the sections were incubated with anti-CRBP-1, Envision-horseradish peroxidase rabbit, and treated with $1 \mathrm{mg} / \mathrm{ml}$ diaminobenzidine, $2.5 \mathrm{mg} / \mathrm{ml}$ Nickel, and $0.1 \% \mathrm{H}_{2} \mathrm{O}_{2}$ in $0.05 \mathrm{M}$ Tris- $\mathrm{HCl}(\mathrm{pH} 7.6)$ at room temperature for 30 minutes.

After washing with water, the sections were counterstained with hematoxylin and mounted with EUKITT (O. Kindler $\mathrm{GmbH}$, Freiburg, Germany). Sections were examined with a Zeiss Axioplan 2 microscope (Carl Zeiss Microscopy, Jena, Germany). Images were acquired with an AxioCam camera (Carl Zeiss Vision, Hallbergmoos, Germany) by means of the AxioVision image processing and analysis system (Carl Zeiss Vision).

\section{Isolation, Culture, and Treatment of Cells}

HSC were isolated from normal adult male SpragueDawley rats (400-500 g body weight) as previously described (Faouzi et al, 1999). An immortalized rat HSC line (HSC-T6), obtained by transfection of 15day-old cultured primary HSC with a CDNA in which the expression of the large T-antigen of SV40 is driven by the Rous sarcoma virus promoter (Vogel et al, 2000), was used. Portal fibroblasts were obtained by outgrowth from the biliary tree, which was isolated according to the collagenase digestion method as previously described, with minor modifications (Ishii et al, 1989; Kumar and Jordan, 1986). Briefly, under anesthesia, the liver was perfused in situ with $\mathrm{Mg}^{++}$ and $\mathrm{Ca}^{++}$-free Hanks' balanced salt solution (HBSS) containing $5 \mathrm{mmol} / \mathrm{l}$ ethylene glycol-bis $(\beta$-aminoethyl ether)-N,N-tetraacetic acid (Sigma, St. Louis, Missouri), $10 \mathrm{mmol} / \mathrm{l}$ HEPES, and $5 \mu \mathrm{g} / \mathrm{ml}$ gentamicin at $37^{\circ} \mathrm{C}$, via a plastic catheter placed into the portal vein. The vena cava was transected and the outflow was allowed to drain freely into the abdominal cavity. Then, the liver was perfused with HBSS containing $0.05 \%$ collagenase (Roche Diagnostic $\mathrm{GmbH}$, Mannheim, Germany), 0.005\% trypsin inhibitor (Sigma), $5 \mathrm{mmol} / \mathrm{l}$
$\mathrm{CaCl}_{2}, 10 \mathrm{mmol} / \mathrm{I}$ HEPES, and gentamicin. The perfused liver was excised and delicately stripped of its capsule with scissors. The remaining liver was then further digested with the same solution as was used in the second perfusion step using gentle shaking and, with further manipulation, the intact portal tract was obtained. The portal tract residue was minced and the pieces incubated for 30 minutes with medium containing $0.1 \%$ pronase (Roche Diagnostic $\mathrm{GmbH}$ ). After digestion, part of the remaining portal tract residues containing exclusively biliary structures was immediately cryopreserved in OCT compound (Sakura; Torrance, California) and snap frozen in liquid nitrogencooled isopentane for immunofluorescence staining. Another part was allowed to adhere in Petri dishes and cultured in Dulbecco's minimum essential medium (DMEM; Life Technologies, Cergy Pontoise, France) supplemented with $100 \mathrm{IU} / \mathrm{ml}$ penicillin and $100 \mu \mathrm{g} / \mathrm{ml}$ streptomycin (Life Technologies) containing 10\% FCS (Life Technologies). After 2 to 3 days, an extensive proliferation of fibroblastic cells was observed along biliary structures. At confluence, cells were trypsinized and seeded in culture medium containing serum. For cell type analysis, immunofluorescence staining was performed as described below.

HSC, HSC-T6, and portal fibroblasts were cultured in DMEM supplemented with penicillin and streptomycin, and $10 \% \mathrm{FCS}$ at $37^{\circ} \mathrm{C}$ in a humidified atmosphere of $95 \% \mathrm{O}_{2}$ and $5 \% \mathrm{CO}_{2}$. When cells reached confluence, they were trypsinized with $2 \mathrm{ml}$ of $0.25 \%$ trypsin (Life Technologies) and passaged. The effect of TGF- $\beta 1$ (R\&D Systems, Oxon, United Kingdom) on CRBP-1 and $\alpha$-SM actin protein expression was evaluated in low serum concentration (1\% FCS) on cultured primary HSC, HSC-T6, and portal fibroblasts after reaching subconfluence. Cells were harvested after 2 days of treatment and used for immunoblotting and Northern blot analysis.

Data were calculated as mean values \pm SEM. The number of experiments ( $n$ ) was indicated. A Student's $t$ test for unpaired samples was used for statistical analysis. A $p<0.05$ was considered significant.

\section{Immunofluorescence Staining}

For immunofluorescence, $5-\mu \mathrm{m}$ serial frozen sections were air-dried on Super frost/plus slides (Menzel Glaser, Germany), fixed in acetone, and incubated with the primary antibodies. Cultured cells were fixed in cold methanol. Oregon green 488-conjugated goat anti-mouse IgG (Molecular Probes, Eugene, Oregon) and/or Alexa Fluor 594-conjugated goat anti-rabbit IgG (Molecular Probes) were used for the second step. Sections or cultured cells were mounted in antifade mounting medium and examined with a Zeiss Axioplan 2 microscope (Carl Zeiss Microscopy, Jena, Germany) equipped with epi-illumination and specific filters.

\section{Immunoblotting Analysis}

Lysates from cultured cells were prepared with lysis buffer: (20 mm Tris- $\mathrm{HCl}, \mathrm{pH} 7.5,0.138 \mathrm{~m} \mathrm{NaCl}, 10 \%$ 
glycerol, 1\% IGEPAL; Sigma), 2 mm EDTA, $2.1 \mathrm{mg} / \mathrm{ml}$ Aprotinin (Sigma), $1 \mu \mathrm{g} / \mathrm{ml}$ Leupeptin, $1 \mu \mathrm{g} / \mathrm{ml}$ Pepstatin A, $0.25 \%$ sodium deoxycholate, and $1 \mathrm{~mm}$ Pefabloc SC (Roche Diagnostics $\mathrm{GmbH}$ ). Sample buffer (0.06 м tris$\mathrm{HCl}, \mathrm{pH} 6.8,2.5 \%$ SDS, $0.72 \mathrm{~m} \beta$-mercaptoethanol, $1.5 \%$ bromophenol blue, final concentrations) was added and samples were boiled for 5 minutes. The loading of the same amounts of protein for each cell population was determined according to Bradford (1976) (three measurements per samples).

Protein aliquots from primary HSC $(5 \mu \mathrm{g})$, HSC-T6 $(30 \mu \mathrm{g})$, or portal fibroblasts $(10 \mu \mathrm{g})$ were subjected to electrophoresis in $15 \%$ SDS-polyacrylamide gels. Resolved proteins were transferred to Immobilon-P membranes (Millipore, Bedford, Massachusetts), which were incubated with blocking buffer $(10 \mathrm{~mm}$ Tris- $\mathrm{HCl}, \mathrm{pH} 8.0,0.1 \mathrm{~m} \mathrm{NaCl}, 0.5 \%$ gelatin, and $0.1 \%$ Tween 20) at room temperature for 1 hour. Membranes were incubated with anti-CRBP-1 antibody or with anti- $\alpha$-SM actin antibody in blocking buffer. Then, membranes were washed with washing buffer $(10 \mathrm{~mm}$ Tris- $\mathrm{HCl}, \mathrm{pH}$ 8.0, $0.1 \mathrm{M} \mathrm{NaCl}$, and $0.1 \%$ Tween 20), and incubated at room temperature for 1 hour with horseradish peroxidase-conjugated swine anti-rabbit IgG (Dako A/S) or horseradish peroxidase-conjugated rabbit anti-mouse IgG (Dako A/S) diluted 1/2,000 with $5 \%$ milk in washing buffer. After washing, enhanced chemiluminescence (Amersham, Les Ulis, France) was used for detection. The molecular weight for CRBP-1 and $\alpha$-SM actin are 15,000 and 43,000 Da, respectively. The signals (arbitrary units) were quantified with the Kodak 1D Image Analysis Software (Eastman Kodak Company, Rochester, New York).

\section{Northern Blot Analysis}

Total RNA was extracted from HSC-T6 cells or portal fibroblasts using the RNeasy Mini kit (Qiagen, Les Ulis, France) according to the manufacturer's instructions. A 5- $\mu$ g amount of total RNA from cultured cells was separated by electrophoresis on a $1 \%$ agarose gel containing ethidium bromide in MOPS buffer. Running buffer and gel contained $0.2 \mathrm{M}$ formaldehyde. The RNAs were transferred onto a positively charged nylon membrane (Hybond-N+; Amersham) by downward capillary transfer in running buffer. Examination of the stained membrane under ultraviolet light was used to confirm the quality of loading and transfer. After ultraviolet cross-linking, prehybridization and hybridization were performed using the ULTRAhyb solution (Ambion, Austin, Texas) at $42^{\circ} \mathrm{C}$. CRBP-1 cDNA probe (Neuville et al, 1997) was labeled with $\left[\alpha^{32} \mathrm{P}\right] \mathrm{dCTP}$ by random priming using the Ready-To-Go kit (Amersham). To further confirm the loading and transfer accuracy, blots were rehybridized with a rat GAPDH cDNA probe (Fort et al, 1985). The signals (arbitrary units) were quantified with the Kodak 1D Image Analysis Software (Eastman Kodak Company). Results are presented as CRBP-1/GAPDH ratios.

\section{Acknowledgments}

We are very grateful to Dr. Schuppan (Department of Gastroenterology, Friedrich-Alexander University, Erlangen, Germany) for providing antibodies against laminin and collagen type IV, to Dr. Zardi (Cell Biology Laboratory, Istituto Nazionale per la Ricerca sul Cancro, Genoa, Italy) for providing antibody against EIIIA domain of fibronectin, and to Dr. Friedman (Department of Medicine, Division of Liver Diseases, Mount Sinai School of Medicine, New York) for HSC-T6 cells.

\section{References}

Bachem MG, Sell KM, Melchior R, Kropf J, Eller T, and Gressner AM (1993). Tumor necrosis factor alpha (TNF alpha) and transforming growth factor beta 1 (TGF beta 1) stimulate fibronectin synthesis and the transdifferentiation of fatstoring cells in the rat liver into myofibroblasts. Virchows Arch B Cell Pathol 63:123-130.

Bhunchet E and Wake K (1992). Role of mesenchymal cell populations in porcine serum-induced rat liver fibrosis. Hepatology 16:1452-1473.

Blaner WS, Hendriks HF, Brouwer A, de Leeuw AM, Knook DL, and Goodman DS (1985). Retinoids, retinoid-binding proteins, and retinyl palmitate hydrolase distributions in different types of rat liver cells. J Lipid Res 26:1241-1251.

Blomhoff R (1994). Transport and metabolism of vitamin A. Nutr Rev 52:S13-S23.

Blomhoff R, Green MH, Berg T, and Norum KR (1990). Transport and storage of vitamin A. Science 250:399-404.

Blomhoff R, Rasmussen M, Nilsson A, Norum KR, Berg T, Blaner WS, Kato M, Mertz JR, Goodman DS, and Eriksson U (1985). Hepatic retinol metabolism. Distribution of retinoids, enzymes, and binding proteins in isolated rat liver cells. J Biol Chem 260:13560-13565.

Borsi L, Carnemolla B, Castellani P, Rosellini C, Vecchio D, Allemanni G, Chang SE, Taylor-Papadimitriou J, Pande $\mathrm{H}$, and Zardi $L$ (1987). Monoclonal antibodies in the analysis of fibronectin isoforms generated by alternative splicing of mRNA precursors in normal and transformed human cells. J Cell Biol 104:595-600.

Bradford MM (1976). A rapid and sensitive method for the quantitation of microgram quantities of protein utilizing the principle of protein-dye binding. Anal Biochem 72:248-254.

Davis BH, Pratt BM, and Madri JA (1987). Retinol and extracellular collagen matrices modulate hepatic Ito cell collagen phenotype and cellular retinol binding protein levels. J Biol Chem 262:10280-10286.

De Bleser PJ, Niki T, Rogiers V, and Geerts A (1997). Transforming growth factor-beta gene expression in normal and fibrotic rat liver. J Hepatol 26:886-893.

Desmoulière A, Darby I, Costa AM, Raccurt M, Tuchweber B, Sommer P, and Gabbiani G (1997). Extracellular matrix deposition, lysyl oxidase expression, and myofibroblastic differentiation during the initial stages of cholestatic fibrosis in the rat. Lab Invest 76:765-778.

Faouzi S, Lepreux S, Bedin C, Dubuisson L, Balabaud C, Bioulac-Sage P, Desmoulière A, and Rosenbaum J (1999). Activation of cultured rat hepatic stellate cells by tumoral hepatocytes. Lab Invest 79:485-493. 
Farrell GC, Bhathal PS, and Powell LW (1977). Abnormal liver function in chronic hypervitaminosis A. Am J Dig Dis 22:724728.

Fort P, Marty L, Piechaczyk M, el Sabrouty S, Dani C, Jeanteur P, and Blanchard JM (1985). Various rat adult tissues express only one major mRNA species from the glyceraldehyde-3-phosphate-dehydrogenase multigenic family. Nucleic Acids Res 13:1431-1442.

Hendriks HF, Verhoofstad WA, Brouwer A, de Leeuw AM, and Knook DL (1985). Perisinusoidal fat-storing cells are the main vitamin A storage sites in rat liver. Exp Cell Res 160:138-149.

Ishii M, Vroman B, and LaRusso NF (1989). Isolation and morphologic characterization of bile duct epithelial cells from normal rat liver. Gastroenterology 97:1236-1247.

Kato M, Kato K, and Goodman DS (1984). Immunocytochemical studies on the localization of plasma and of cellular retinol-binding proteins and of transthyretin (prealbumin) in rat liver and kidney. J Cell Biol 98:1696-1704.

Kent G, Gay S, Inouye T, Bahu R, Minick OT, and Popper H (1976). Vitamin A-containing lipocytes and formation of type III collagen in liver injury. Proc Natl Acad Sci USA 73:37193722.

Knittel T, Kobold D, Piscaglia F, Saile B, Neubauer K, Mehde M, Timpl R, and Ramadori G (1999a). Localization of liver myofibroblasts and hepatic stellate cells in normal and diseased rat livers: distinct roles of (myo-)fibroblast subpopulations in hepatic tissue repair. Histochem Cell Biol 112:387401.

Knittel T, Kobold D, Saile B, Grundmann A, Neubauer K, Piscaglia F, and Ramadori G (1999b). Rat liver myofibroblasts and hepatic stellate cells: Different cell populations of the fibroblast lineage with fibrogenic potential. Gastroenterology 117:1205-1221.

Kumar $U$ and Jordan TW (1986). Isolation and culture of biliary epithelial cells from the biliary tract fraction of normal rats. Liver 6:369-378.

Manabe N, Chevallier M, Chossegros P, Causse X, Guerret S, Trepo C, and Grimaud JA (1993). Interferon-alpha 2b therapy reduces liver fibrosis in chronic non-A, non-B hepatitis: $A$ quantitative histological evaluation. Hepatology 18:13441349.

Milani S, Herbst H, Schuppan D, Stein H, and Surrenti C (1991). Transforming growth factors beta 1 and beta 2 are differentially expressed in fibrotic liver disease. Am J Pathol 139:1221-1229.

Neuville P, Geinoz A, Benzonana G, Redard M, Gabbiani F, Ropraz P, and Gabbiani G (1997). Cellular retinol-binding protein-1 is expressed by distinct subsets of rat arterial smooth muscle cells in vitro and in vivo. Am $\mathrm{J}$ Pathol 150:509-521.

Ohata M, Lin M, Satre M, and Tsukamoto H (1997). Diminished retinoic acid signaling in hepatic stellate cells in cholestatic liver fibrosis. Am J Physiol 272:G589-596.

Ong DE, Newcomer ME, and Chytil F (1994). Cellular retinoidbinding proteins. In: Sporn MB, Roberts $A B$, and Goodman DS, editors. The Retinoids: Biology, Chemistry and Medicine. NewYork: Raven Press, 283-317.

Pinzani M and Gentilini P (1999). Biology of hepatic stellate cells and their possible relevance in the pathogenesis of portal hypertension in cirrhosis. Semin Liver Dis 19:397-410.
Ramadori G, Veit T, Schwogler S, Dienes HP, Knittel T, Rieder H, and Meyer zum Buschenfelde KH (1990). Expression of the gene of the alpha-smooth muscle-actin isoform in rat liver and in rat fat-storing (ITO) cells. Virchows Arch B Cell Pathol Incl Mol Pathol 59:349-357.

Rockey DC, Boyles JK, Gabbiani G, Friedman SL (1992). Rat hepatic lipocytes express smooth muscle actin upon activation in vivo and in culture. J Submicrosc Cytol Pathol 24:193-203.

Ross AC (1993a). Cellular metabolism and activation of retinoids: Roles of cellular retinoid-binding proteins. Faseb $\mathrm{J}$ 7:317-327.

Ross AC (1993b). Overview of retinoid metabolism. J Nutr 123:346-350.

Russell RM, Boyer JL, Bagheri SA, and Hruban Z (1974). Hepatic injury from chronic hypervitaminosis $A$ resulting in portal hypertension and ascites. N Engl J Med 291:435-440.

Seifert WF, Bosma A, Brouwer A, Hendriks HF, Roholl PJ, van Leeuwen RE, van Thiel-de Ruiter GC, Seifert-Bock I, and Knook DL (1994). Vitamin A deficiency potentiates carbon tetrachloride-induced liver fibrosis in rats. Hepatology 19: 193-201.

Senoo $H$ and Wake K (1985). Suppression of experimental hepatic fibrosis by administration of vitamin A. Lab Invest 52:182-194.

Sherman DR, Lloyd RS, and Chytil F (1987). Rat cellular retinol-binding protein: cDNA sequence and rapid retinoldependent accumulation of mRNA. Proc Natl Acad Sci USA 84:3209-3213.

Shiratori Y, Ichida T, Geerts A, and Wisse E (1987). Modulation of collagen synthesis by fat-storing cells, isolated from $\mathrm{CCl}_{4}$ - or vitamin A-treated rats. Dig Dis Sci 32:1281-1289.

Skalli O, Ropraz P, Trzeciak A, Benzonana G, Gillessen D, and Gabbiani G (1986). A monoclonal antibody against alpha-smooth muscle actin: a new probe for smooth muscle differentiation. J Cell Biol 103:2787-2796.

Tuchweber B, Desmoulière A, Bochaton-Piallat ML, RubbiaBrandt L, and Gabbiani G (1996). Proliferation and phenotypic modulation of portal fibroblasts in the early stages of cholestatic fibrosis in the rat. Lab Invest 74:265-278.

Vicente CP, Fortuna VA, Margis R, Trugo L, and Borojevic R (1998). Retinol uptake and metabolism, and cellular retinol binding protein expression in an in vitro model of hepatic stellate cells. Mol Cell Biochem 187:11-21.

Vogel S, Piantedosi R, Frank J, Lalazar A, Rockey DC, Friedman SL, and Blaner WS (2000). An immortalized rat liver stellate cell line (HSC-T6): a new cell model for the study of retinoid metabolism in vitro. $\mathrm{J}$ Lipid Res 41:882-893.

Xu G, Bochaton-Piallat ML, Andreutti D, Low RB, Gabbiani G, and Neuville $P$ (2001). Regulation of alpha-smooth muscle actin and CRBP-1 expression by retinoic acid and TGF-beta in cultured fibroblasts. J Cell Physiol 187:315-325.

Xu G, Redard M, Gabbiani G, and Neuville P (1997). Cellular retinol-binding protein-1 is transiently expressed in granulation tissue fibroblasts and differentially expressed in fibroblasts cultured from different organs. Am J Pathol 151:17411749.

Yamane M, Tanaka Y, Marumo F, and Sato C (1993). Role of hepatic vitamin $A$ and lipocyte distribution in experimental hepatic fibrosis. Liver 13:282-287. 